\title{
PENGEMBANGAN PERANGKAT LUNAK GENERATE FILE AKUN UANG KULIAH TUNGGAL (UKT) UNIVERSITAS PALANGKA RAYA
}

\author{
Viktor Handrianus Pranatawijaya1), Putu Bagus Adidyana Anugrah Putra ${ }^{2)}$, \\ Widiatry $^{3)}$, Nova Noor Kamala Sari ${ }^{4}$. \\ 1,2,3,4) Program Studi Teknik Informatika Universitas Palangka Raya \\ Kampus Unpar Tunjung Nyaho Jl. Yos Sudarso Palangka Raya \\ Email: viktorhp@upr.ac.id ${ }^{1)}$,putubagus@it.upr.ac.id²), \\ widiatry@it.upr.ac.id ${ }^{3)}$, novanoorks@it.upr.ac.id ${ }^{4)}$
}

\begin{abstract}
Regulations concerning Single Tuition Fee have been contained in the Regulation of Minister of Research, Technology and Higher Education Number 39 of 2016. In addition, the Law on Higher Education Number 12 of 2012 Article 88 stipulates that the minister posseses the authority to set the unit standard for Higher Education operational costs which becomes the basis of state universities to set the costs charged by the students in the scope of Ministry of Research, Technology and Higher Education.

University of Palangka Raya applies Generate File Software Development Account to determine the cost of Single Tuition Fee which is a development method of modified Waterfall software. This method consists of four stages; (1) Analysis; (2) Design; (3) Implementation, and; (4) Testing. Quicksort and Depth First Search Algorithm also implemented on system.

Thus this website utilizes Generate Data Account of Single Tuition Fee which will work automatically from each Higher Education entry, namely SNMPTN, SBMPTN and SMMPTNBARAT and create easier to the management team to change automatically the data of study program from students' Singgle Tuition Fee account based on the specified study program.
\end{abstract}

Keywords: Single Tuition Fee, Generate File, Quicksort, Depth First Search

\section{PENDAHULUAN}

Peraturan tentang Biaya Kuliah Tunggal (BKT) dan Uang Kuliah Tunggal (UKT) telah dimuat dalam PERMEN RISTEKDIKTI Nomor 39 Tahun 2016. Sedangkan UndangUndang tentang Pendidikan Tinggi Nomor 12 Tahun 2012 Pasal 88 menetapkan bahwa menteri berwenang menetapkan standar satuan biaya operasional Pendidikan Tinggi yang menjadi dasar perguruan tinggi negeri dalam menetapkan biaya yang ditanggung oleh mahasiswa di lingkungan Kementerian Riset, Teknologi, dan Pendidikan Tinggi.

Untuk meningkatkan kualitas pelayanan publik seperti pelayanan penetapan UKT mahasiswa baru, perguruan tinggi khususnya di Universitas Palangka Raya dalam pengolahan dan pengelolaan data sudah mengunakan sistem informasi berbasis website. Jadi, calon mahasiswa tidak 
lagi harus mengantri di loket untuk melengkapi berkas-berkas yang dibutuhkan untuk penentuan UKT yang harus dibayarkan calon mahasiswa tersebut. Mahasiswa cukup mengisi dan melengkapi form UKT secara online dimana saja calon mahasiswa itu berada. Namun, ada proses-proses yang masih dilakukan secara manual sehingga dalam hal pengerjaannya membutuhkan waktu yang cukup banyak, seperti pengolahan akun UKT calon mahasiswa.

Universitas Palangka Raya menerima calon mahasiswa melalui tiga jalur masuk Perguruan Tinggi: SNMPTN (Seleksi Nasional Masuk Perguruan Tinggi Negeri), SBMPTN (Seleksi Bersama Masuk Perguruan Tinggi Negeri) dan SMMPTN-BARAT (Seleksi Mandiri Masuk Perguruan Tinggi Negeri Wilayah Barat). Data calon mahasiswa yang diterima memalui tiga jalur SNMPTN, SBMPTN dan SMMPTN-BARAT tersebut memiliki struktur data yang berbedabeda, sehingga dalam pengolahan akun UKT masih memerlukan waktu, serta ketepatan dan keakuratan informasi terkadang masih belum tercapai karena masih dikelola secara manual menggunakan aplikasi perkantoran Microsoft Excel.

Sehubungan dengan pemanfaatan Microsoft Excel, peneliti sebelumnya juga telah melakukan penelitian untuk mengembangkan perangkat lunak generate file untuk import data ke feeder PDDIKTI (Pranatawijaya dkk., 2016). Sistem Informasi Praktikum Pada Jurusan Teknik Informatika Universitas Palangkaraya Berbasis Web (Pranatawijaya,2016) dapat digunakan sebagai dasar dalam pembuatan otomatisasi pembuatan informasi berdasarkan data-data tertentu. Dan yang terakhir adalah Analisis Dan Desain Website Monitoring Konsultasi Bimbingan Kartu Rencana Studi (KRS) (Putra dkk.,2017) dan Rancang Bangun Sistem Informasi Pencarian Data Mahasiswa dan Dosen Pada Fakultas Hukum Universitas Palangka Raya (Putra, P.B.A.A., 2017) memberikan cara untuk pengelolaan data yang akan dimigrasi dan pemahaman dalam teknik searching data. Sehingga, tujuan penelitian ini adalah mengembangkan perangkat lunak generate file akun UKT Universitas Palangka Raya sehingga dapat menjadi suatu pondasi untuk mengimplementasikan sistem tersebut nantinya. 


\section{METODE PENELITIAN}

Berikut ini merupakan beberapa tahapan penelitian, yaitu:

1) Studi Pustaka dan Observasi

Metode ini melakukan studi pustaka terhadap buku, jurnal ilmiah nasional dan internasional sebagai pendukung dalam penelitian. Observasi dilakukan untuk mengambil data-data untuk titik dan berapa besar radius yang diperlukan untuk menandakan suatu ruangan yang nantinya akan dijadikan area untuk mengeluarkan informasi.

2) Analisis Sistem

Proses pencarian kebutuhan difokuskan pada software untuk mengetahui sifat dari website yang akan dibuat, pemodelan proses bisnis menggunakan Data Flow Diagram (DFD) dan Entity Relationship Diagram (ERD).

Data Flow Diagram atau yang disingkat DFD merupakan diagram yang menggambarkan alir data dalam suatu entitas ke sistem atau sistem ke entitas. DFD juga dapat diartikan sebagai teknik grafis yang menggambarkan alir data dan transformasi yang digunakan sebagai perjalanan data dari input atau masukan menuju keluaran atau output.

Entity Relationship Diagram (ERD) adalah diagram yang menghubungkan antar entitas di dalam penyusunan/perancangan basis data. Diagram Entitiy Relationaship ini ditemukan oleh Chen tahun 1976. Tujuan dari Entity Relationship Diagram adalah untuk menunjukkan objek data dan relationship yang ada pada objek tersebut

3) Desain Sistem

Proses ini digunakan untuk membuat "blueprint" software seperti, perancangan basis data dan perancangan antarmuka (interface).

4) Implementasi

Proses ini akan dilakukan pembuatan perangkat lunak sesuai dengan perancangan basis data dan antar muka yang telah dilakukan pada tahap sebelumnya.

5) Pengujian Sistem

Proses pengujian akan dilakukan dengan Blackbox Testing yang disertai dengan melakukan simulasi data. Pengujian Black Box adalah pengujian aspek fundamental sistem tanpa memperhatikan struktur logika internal perangkat 
lunak. Metode ini digunakan untuk mengetahui apakah perangkat lunak berfungsi dengan benar. Pengujian black box merupakan metode perancangan data uji yang didasarkan pada spesifikasi perangkat lunak. Data uji dieksekusi pada perangkat lunak dan kemudian keluar dari perangkat lunak dicek apakah telah sesuai yang diharapkan. Tujuan utama pengujian haruslah untuk mengekspos kesalahan dalam perangkat lunak dan untuk menghindari potensi kegagalan (B. Harsh dkk., 2014).

\section{Model yang digunakan}

Model yang digunakan merupakan suatu hasil dari siklus hidup pengembangan perangkat lunak Model Waterfall. Pada perkembangannya banyak bermunculan modifikasimodifikasi dari model tersebut. Sehingga model yang digunakan pada penelitian ini merupakan model model Waterfall yang modifikasi. Tahapan yang dilakukan yaitu pada tahap analisis, desain, implementasi dan pengujian

\section{HASIL DAN PEMBAHASAN}

Website yang akan dibuat adalah untuk mengenerate akun UKT. Tahaptahapnya adalah melakukan (i) setting variabel dan referensi tabel-tabel pada sistem, (ii) import file excel berdasarkan jalur masuk SNMPTN, SBMPTN dan SMMPTN-Barat. Pada bagian ini terbagi dai tiga proses yaitu (a) sorting data jurusan dan nomor peserta menggunakan algoritma Quicksort (Thomas H. Cormen, 2001), (b) looping untuk otomasi pengaturan format data dan referensi data untuk akun UKT serta data matching untuk referensi berdasarkan algoritma Depth First Search (pencarian mendalam pertama) (Widiatri, 2016). Penambahan data yang diolah ke dalam tabel-tabel yang ada pada sistem. Dan tahap terakhir adalah (iii) export data pada tabel-tabel di sistem menjadi file excel akun UKT dengan cara menentukan field-field yang diperlukan beserta query yang ideal untuk mengoptimasikan waktu proses eksekusi. Sebagai contoh tidak menggunakan * (bintang) setelah select dan langsung pada field-field yang diperlukan.

Proses modeling pada sistem yang dibuat menerjemahkan syarat kebutuhan 
ke sebuah perancangan software yang dapat diperkirakan sebelum dibuat coding. Proses ini terbagi menjadi 2, yaitu analisis dan desain. Pada analisis menggunakan Data Flow Diagram (DFD) serta Entity Relationship Diagram (ERD). Pada desain akan dilakukan desain tabel, desain navigasi mengunakan Sitemap dan desain antarmuka/representasi interface. Tahapan ini akan menghasilkan dokumen yang disebut software requirement.

Diagram Konteks digunakan untuk menggambarkan sistem perangkat lunak untuk membuat Template File Akun Uang Kuliah Tunggal (UKT) Universitas Palangka Raya Berbasis web secara garis besar atau keseluruhan.
Diagram Konteks ini dirancang memperhatikan masukan yang dibutuhkan oleh sistem dan keluaran yang dihasilkan oleh sistem. Diagram Konteks dapat dilihat pada gambar 1 berikut.

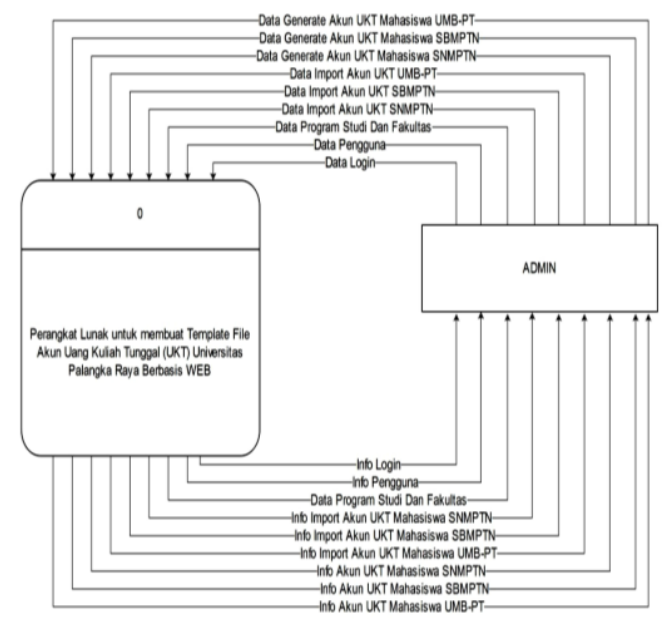

Gambar 1. Diagram Konteks Perangkat Lunak Template File Akun UKT 


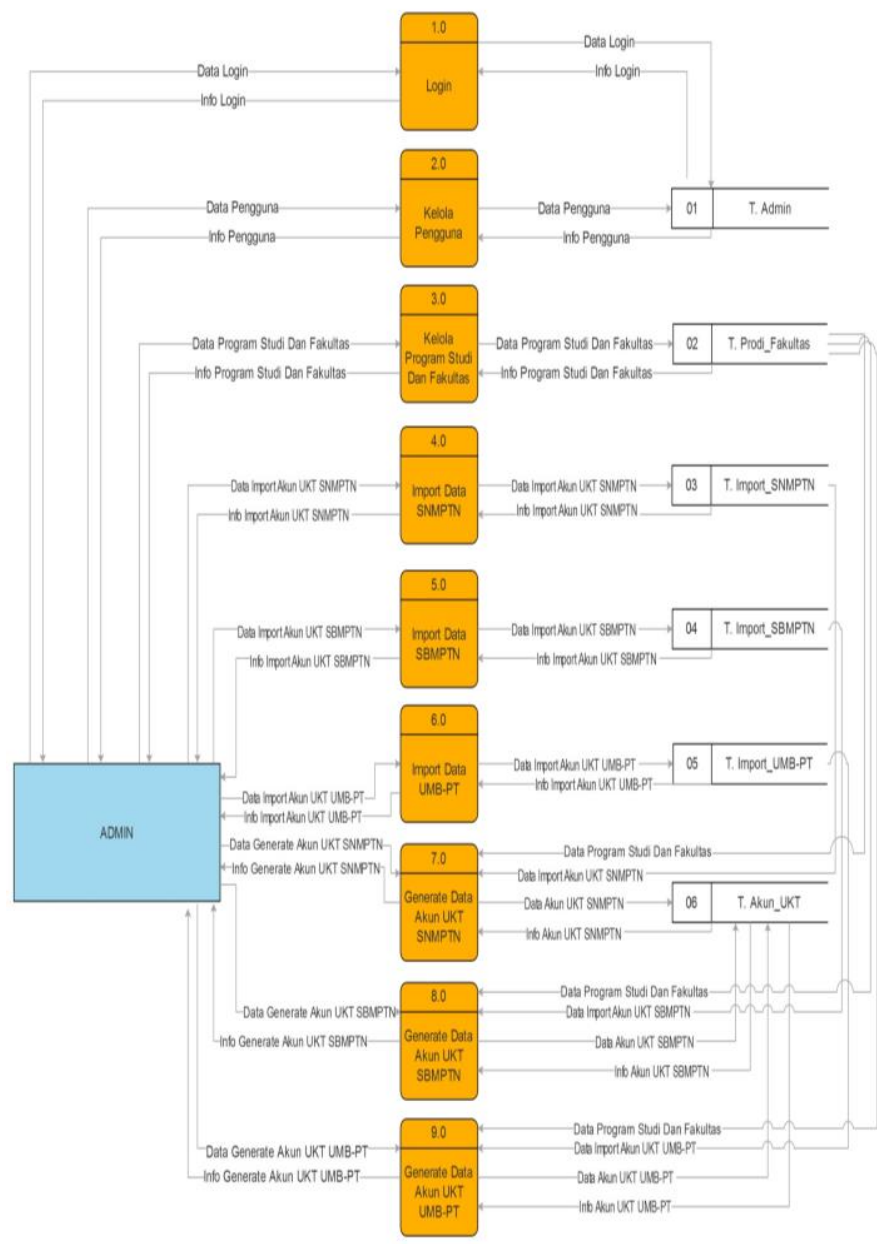

Gambar 2. DFD Level-1

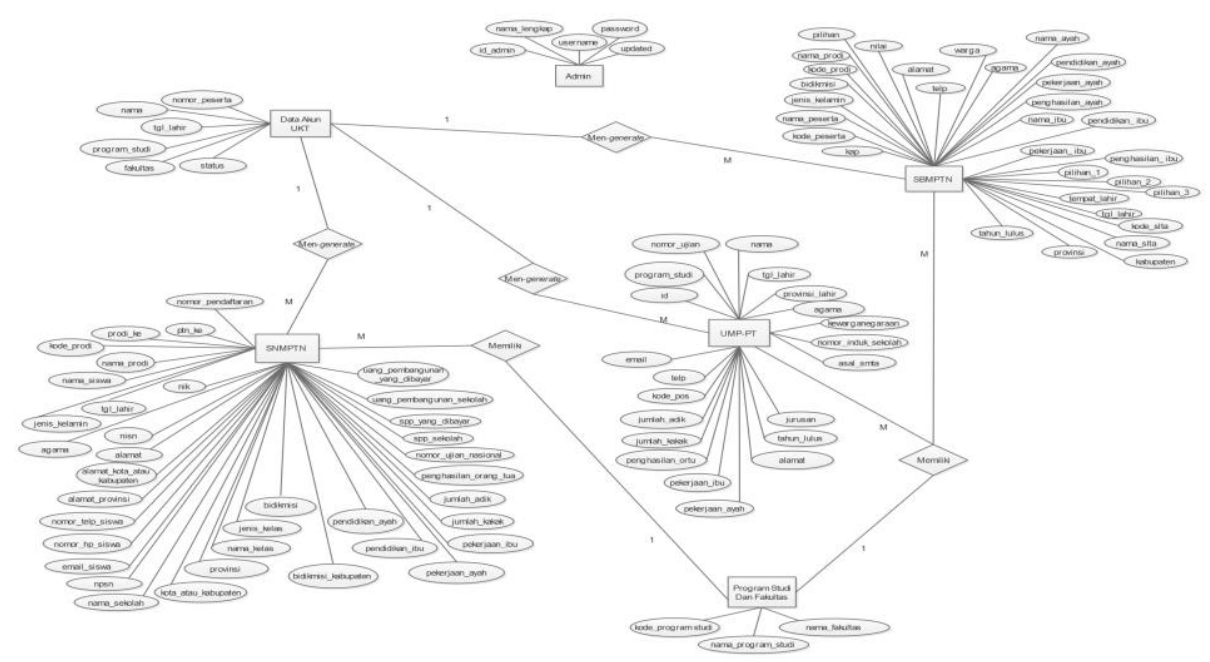

Gambar 3. ERD 


\section{Desain Navigasi}

Desain navigasi menggunakan

MAHASISWA

Sitemap. Pada website ini yaitu Sitemap Admin (Pengguna). Sitemap Admin pada Template File Akun Uang Kuliah Tunggal (UKT) Universitas Palangka Raya Berbasis WEB, yaitu seperti pada gambar 4 berikut.

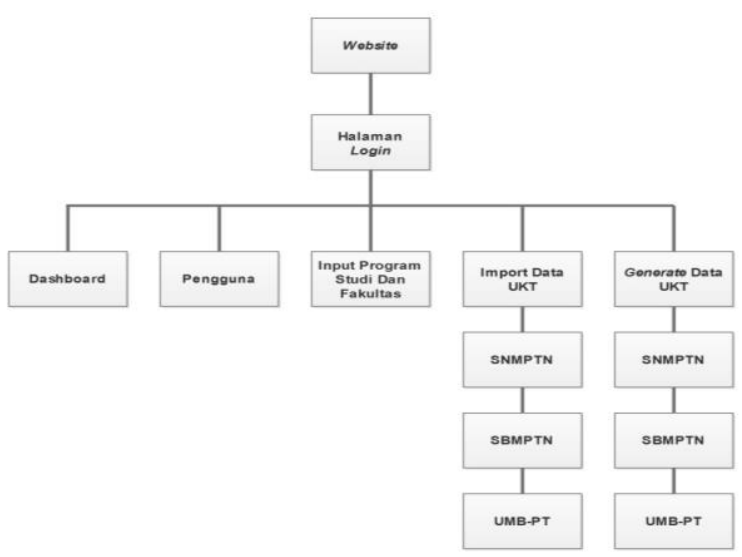

Gambar 4. Sitemap Admin

\section{Implementasi Antarmuka}

Untuk perancangan antarmuka digunakan dua metode pemrograman, aplikasi server menggunakan Database $M y S Q L$ dan aplikasi website menggunakan PHP. Pada implementasi antarmuka Website Perangkat Lunak Untuk Membuat Template File Akun Uang Kuliah Tunggal (UKT) Universitas Palangka Raya ini yaitu implementasi antarmuka halaman admin

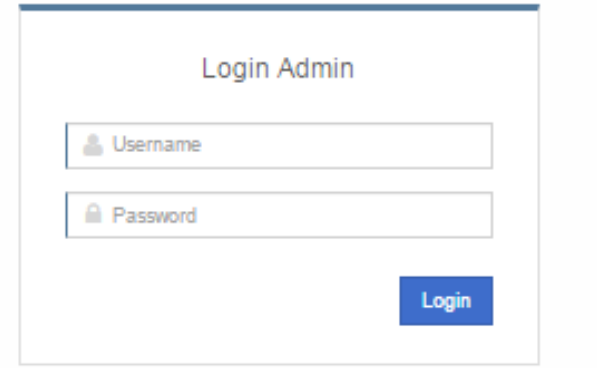

Gambar 5. Implementasi Halaman Login Admin

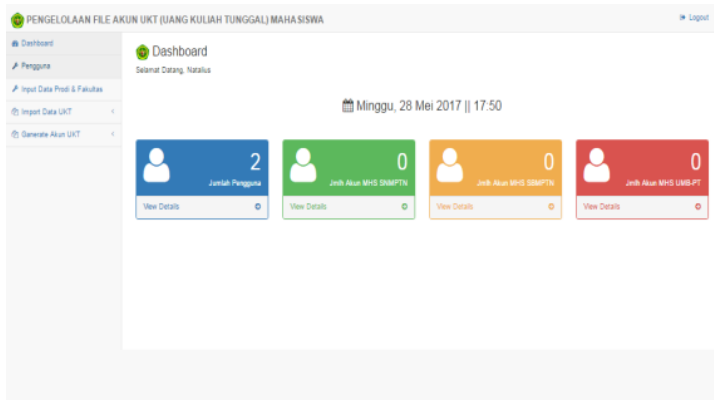

Gambar 6 Implementasi Halaman Dashboard

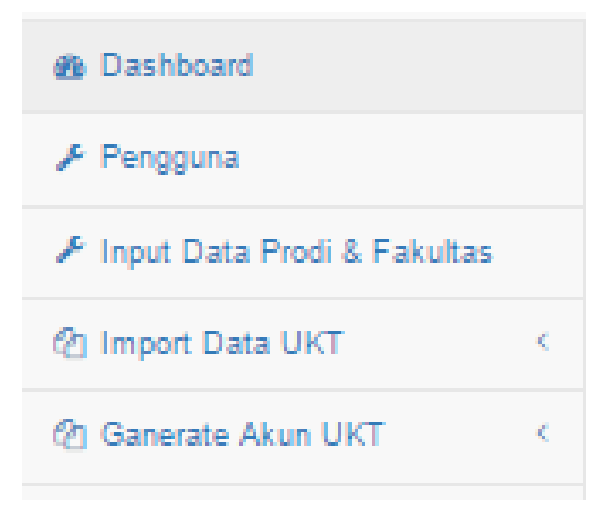

Gambar 7. Implementasi Sidebar Menu Admin 


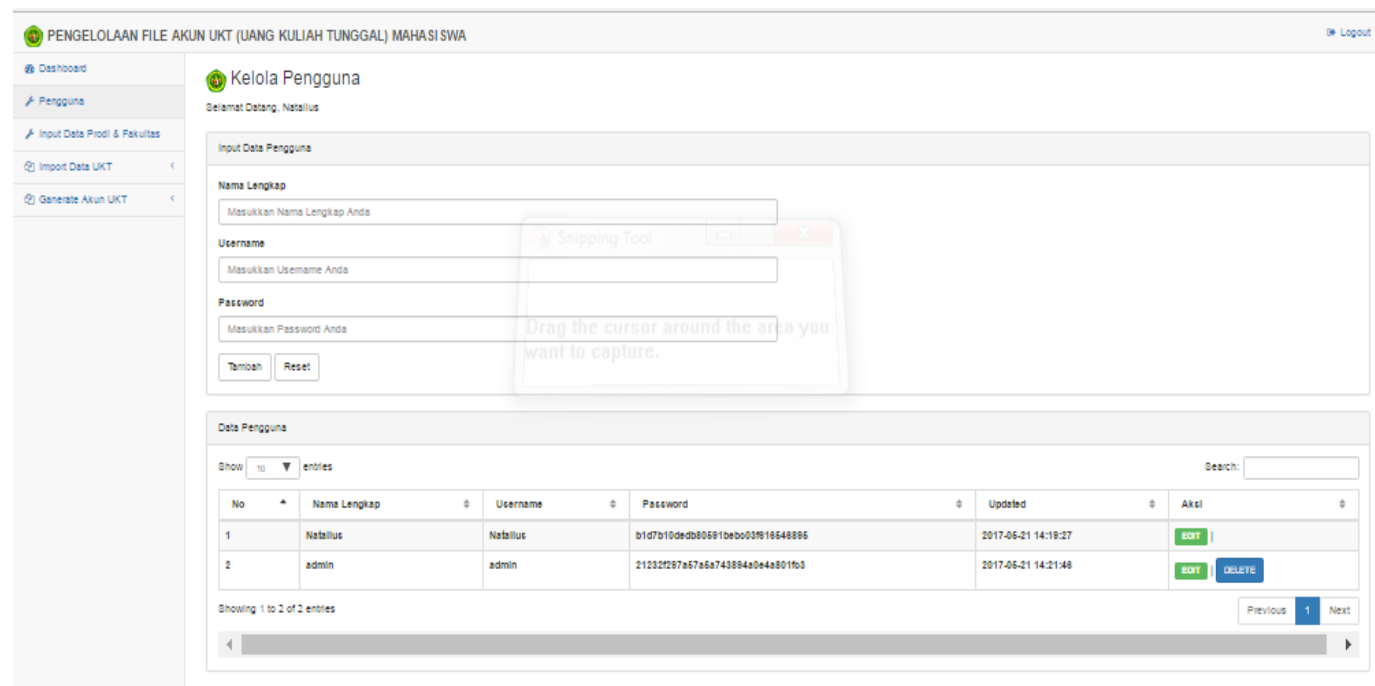

Gambar 8. Implementasi Halaman Pengguna (Admin)

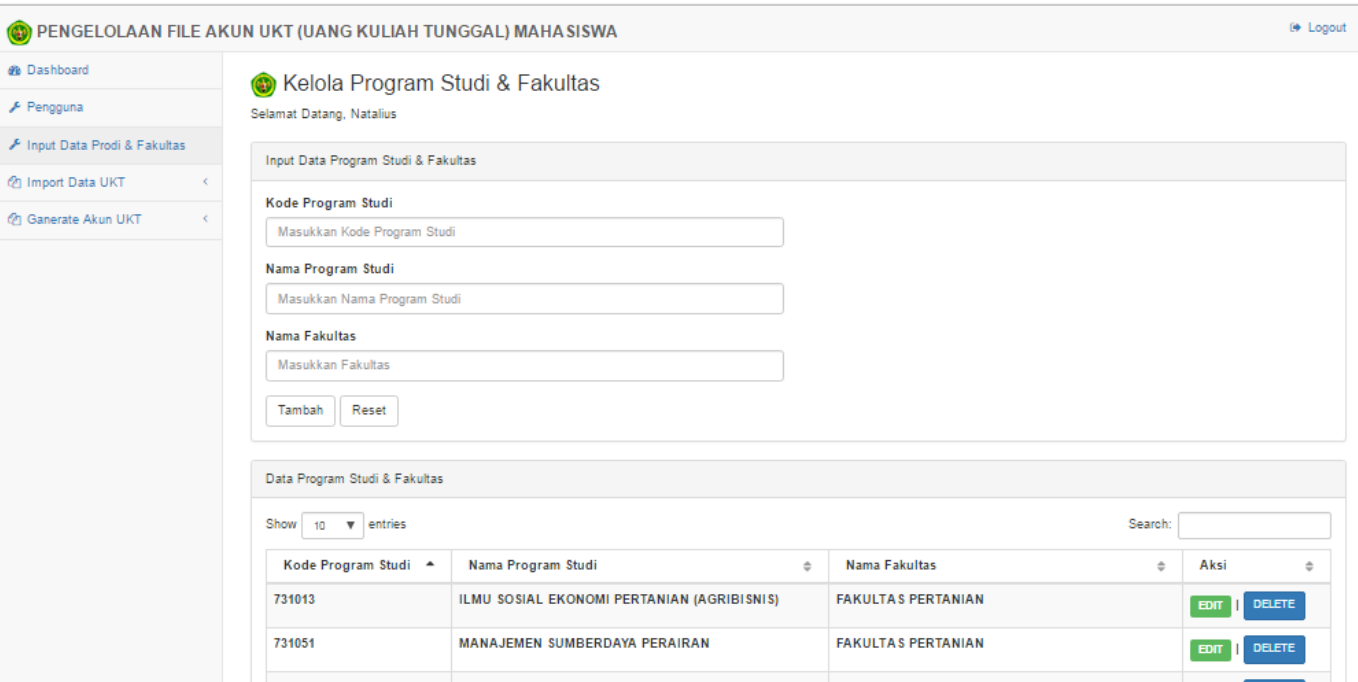

Gambar 9. Implementasi Halaman Input Prodi \& Fakultas

\section{Implementasi Halaman Data Import SNMPTN, SBMPTN, dan SMMPTN-} BARAT

Implementasi halaman import data akun UKT mahasiswa sesuai dengan jalur masuk perguruan Tinggi Negeri yang terpilih berfungsi untuk menambah data akun mahasiswa dengan cara mengimport data dari file yang berformat .xls (Microsoft Excel 2003).
Proses import SNMPTN yang dilakukan salah satunya adalah mengolah data tanggal lahir dan jurusan menjadi sesuai pada format data akun UKT yang telah ditentukan. Sedangkan salah satu proses import SBMPTN yang dilakukan adalah mengolah data jumlah prodi dan pengaturan tabel referensi tabel program studi serta fakultas sesuai pada format data akun UKT yang telah ditentukan. Pada 
kedua proses ini dilakukan secara otomatis

oleh sistem.

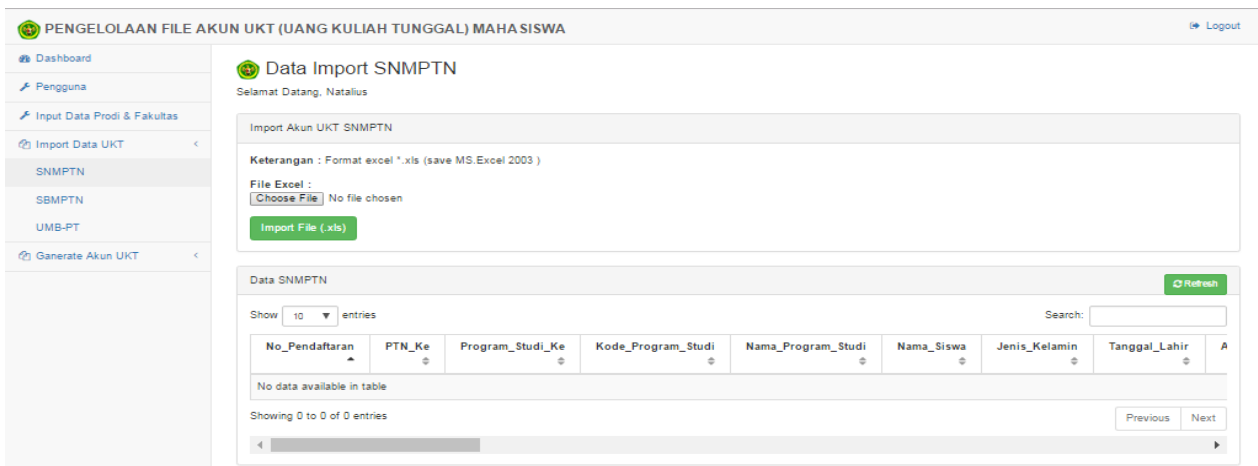

Gambar 10. Implementasi Halaman Data Import SNMPTN

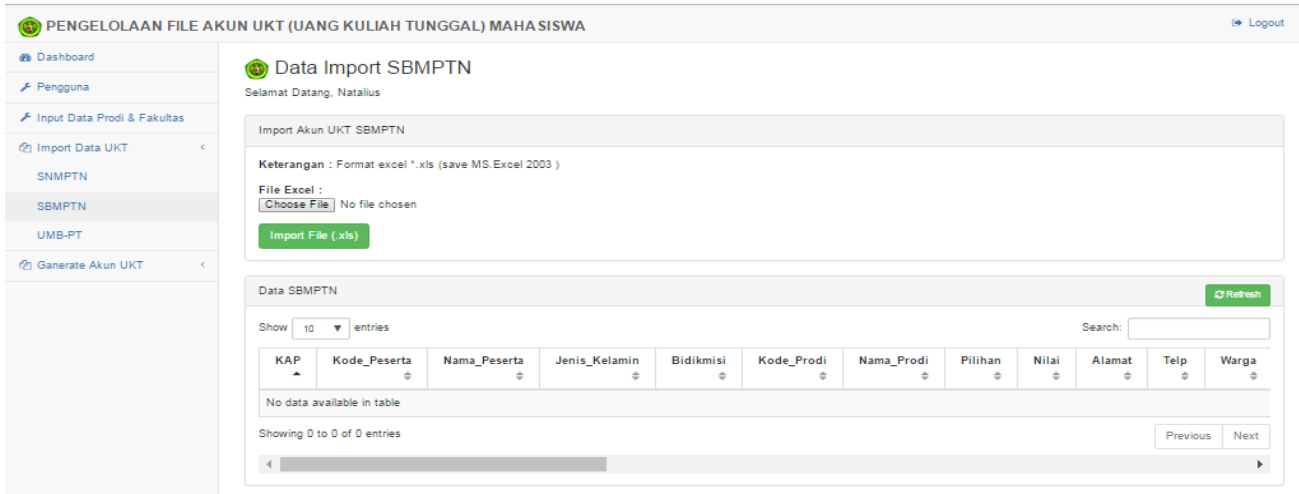

Gambar 11. Implementasi Halaman Data Import SBMPTN

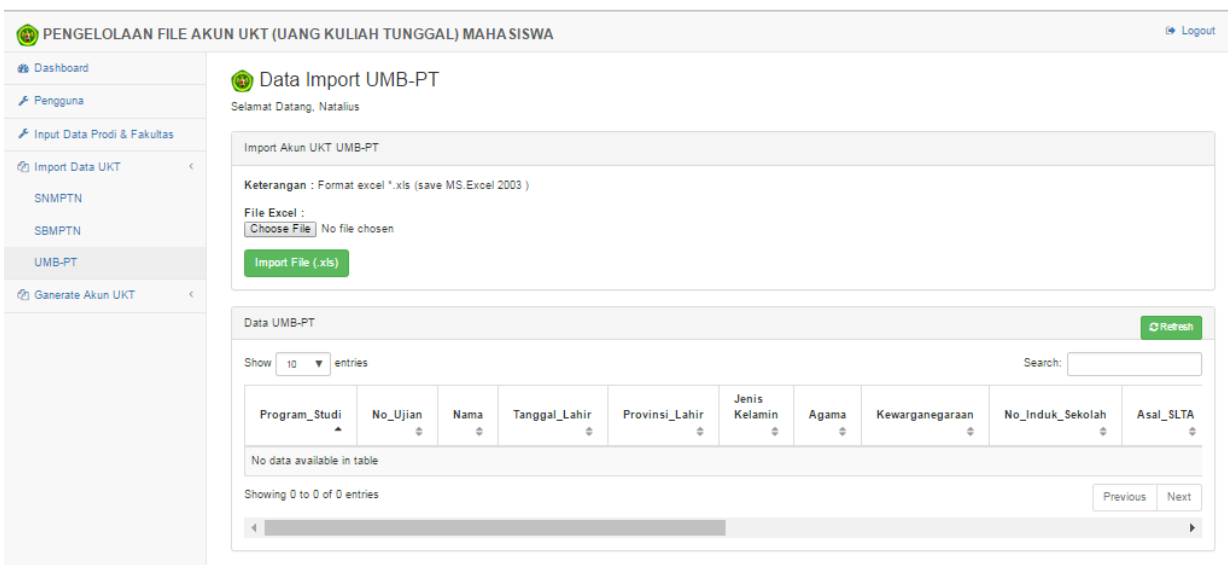

Gambar 12. Implementasi Halaman Data Import SMMPTN-BARAT 
Implementasi Halaman Generate Data Akun SNMPTN, SBMPTN, dan SMMPTN-BARAT

Implementasi halaman generate data berfungsi untuk membuat data akun UKT secara otomatis sesuai dengan jalur masuk perguruan Tinggi Negeri yang terpilih. Pada halaman ini juga terdapat tombol export data akun sesuai dengan jalur masuk perguruan Tinggi Negeri ke microsoft excel dengan format xls.

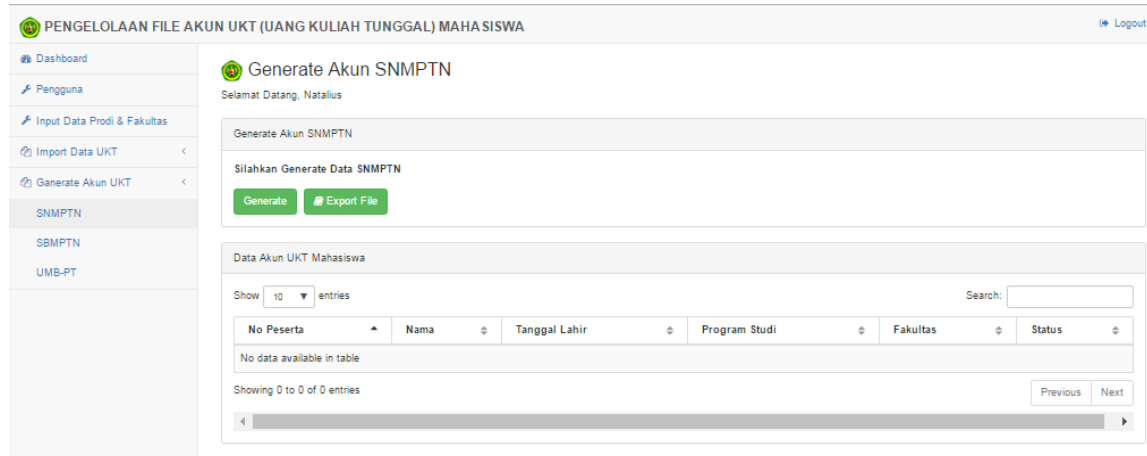

Gambar 13. Implementasi Halaman Generate Data Akun SNMPTN

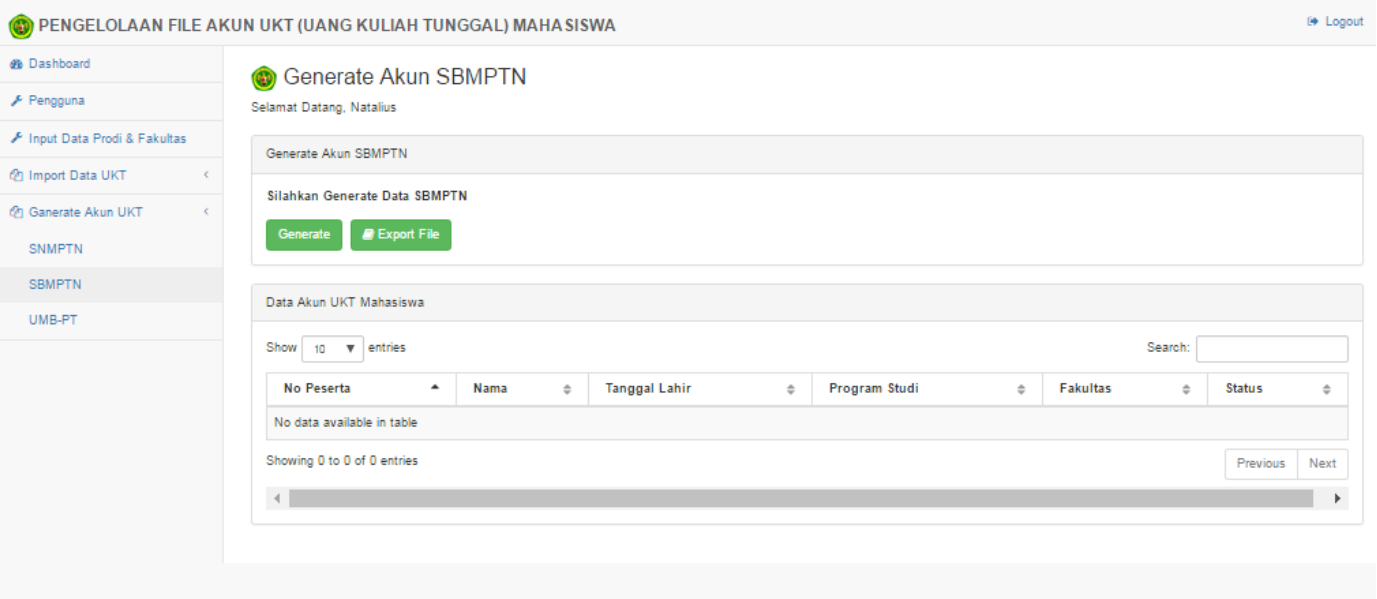

Gambar 14. Implementasi Halaman Generate Data Akun SBMPTN 


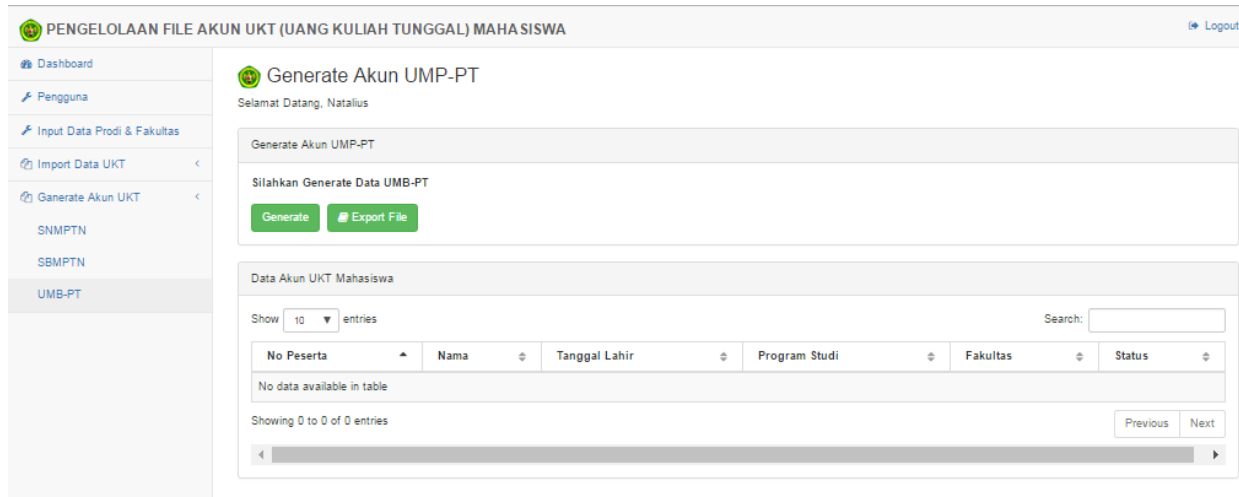

Gambar 15. Implementasi Halaman Generate Data Akun SMMPTN-BARAT

Format data mahasiswa pada masingmasing jalur berbeda, sebagai contoh format tanggal lahir, kode jurusan jurusan, dan nama fakultas, jumlah datanya tidak sama. Sehingga diperlukan perlakuan yang khusus pada masing-masing jalur masuk Perguruan Tinggi Negeri, agar proses otomatisasi data-data yang diperlukan pada data akun UKT dapat dibuat.

Tabel 1. Blacbox Testing Admin

\begin{tabular}{|c|c|c|c|}
\hline No & Halaman & Proses & Hasil \\
\hline 1 & 2 & 3 & 4 \\
\hline 1 & Login Admin & $\begin{array}{l}\text { 1. Menginputkan password tanpa username (tidak } \\
\text { dapat masuk) } \\
\text { 2. Menginputkan username tanpa password (tidak } \\
\text { dapat masuk) } \\
\text { 3. Tidak menginputkan username dan password (tidak } \\
\text { dapat masuk) } \\
\text { 4. Menginputkan username benar dan password salah } \\
\text { (tidak dapat masuk) } \\
\text { 5. Menginputkan password benar dan username salah } \\
\text { (tidak dapat masuk) } \\
\text { 6. Menginputkan username dan password benar } \\
\text { (dapat masuk ke halaman dashboard admin) }\end{array}$ & $\mathrm{OK}$ \\
\hline 2 & Dashboard & $\begin{array}{l}\text { Menampilkan halaman dashboard/ } \\
\text { halaman utama admin }\end{array}$ & $\mathrm{OK}$ \\
\hline 3 & Pengguna & $\begin{array}{l}\text { 1. Satu data pengguna tidak bisa terhapus } \\
\text { 2. Menambah data pengguna } \\
\text { 3. Mengubah data pengguna } \\
\text { 4. Menghapus data pengguna }\end{array}$ & OK \\
\hline 4 & $\begin{array}{l}\text { Input Prodi \& } \\
\text { Fakultas }\end{array}$ & $\begin{array}{l}\text { 1. Menambah data prodi dan fakultas } \\
\text { 2. Mengubah data prodi dan fakultas } \\
\text { 3. Menghapus data prodi dan fakultas }\end{array}$ & $\mathrm{OK}$ \\
\hline 5 & $\begin{array}{l}\text { Import } \\
\text { SNMPTN }\end{array}$ & $\begin{array}{l}\text { Mengimport data akun UKT mahasiswa SNMPTN dengan } \\
\text { memilih file yang akan diimport }\end{array}$ & $\mathrm{OK}$ \\
\hline 6 & $\begin{array}{l}\text { Import } \\
\text { SBMPTN }\end{array}$ & $\begin{array}{l}\text { Mengimport data akun UKT mahasiswa SBMPTN dengan } \\
\text { memilih file yang akan diimport }\end{array}$ & OK \\
\hline
\end{tabular}




\begin{tabular}{|c|l|l|c|}
\hline No & \multicolumn{1}{|c|}{ Halaman } & \multicolumn{1}{|c|}{ Proses } & Hasil \\
\hline 1 & \multicolumn{1}{|c|}{2} & \multicolumn{1}{|c|}{3} & 4 \\
\hline 7 & $\begin{array}{l}\text { Import } \\
\text { SMMPTN- } \\
\text { BARAT }\end{array}$ & $\begin{array}{l}\text { Mengimport data akun UKT mahasiswa SMMPTN- } \\
\text { BARAT dengan memilih file yang akan diimport }\end{array}$ & OK \\
\hline 8 & $\begin{array}{l}\text { Generate Akun } \\
\text { UKT SNMPTN }\end{array}$ & $\begin{array}{l}\text { Generate data akun SNMPTN secara otomatis dan export } \\
\text { data akun SNMPTN yang telah digenerate }\end{array}$ & OK \\
\hline 9 & $\begin{array}{l}\text { Generate Akun } \\
\text { UKT SBMPTN }\end{array}$ & $\begin{array}{l}\text { Generate data akun SBMPTN secara otomatis dan export } \\
\text { data akun SBMPTN yang telah digenerate }\end{array}$ & OK \\
\hline 10 & $\begin{array}{l}\text { Generate Akun } \\
\text { UKT SMMPTN- } \\
\text { BARAT }\end{array}$ & $\begin{array}{l}\text { Generate data akun SMMPTN-BARAT secara otomatis } \\
\text { dan export data akun SMMPTN-BARAT yang telah } \\
\text { degenerate }\end{array}$ & OK \\
\hline 11 & Log Out & Logout (Admin ke halaman login) & OK \\
\hline
\end{tabular}

\section{KESIMPULAN}

Dalam Pengembangan Perangkat Lunak Generate File Akun Uang Kuliah Tunggal (UKT) Universitas Palangka Raya digunakan metode pengembangan perangkat lunak Waterfall yang telah dimodifikasi dan terdiri atas 4 tahapan, yaitu Analisis sistem seperti mendapatkan kebutuhan data dan teknologi yang digunakan pada proses bisnis dan rencana kegiatan, Data Flow Diagram dan Entity Relationship Diagram dilakukan juga. Pada desain dilakukan desain tabel, desain navigasi menggunakan sitemap, dan desain antarmuka dan Implementasi dilakukan dengan bahasa pemrograman PHP. Pada tahap Pengujian menggunakan Blackbox Testing. Website ini menggunakan Generate data akun UKT secara otomatis dari tiap jalur masuk Perguruan Tinggi yaitu SNMPTN, SBMPTN dan SMMPTNBARAT tanpa harus melakukan pengaturan untuk menyesuaikan format dan referensi pada data akun UKT.
Algoritma Quickshort dan Depth First Search juga diterapkan pada proses generate data akun UKT. Penentuan query untuk pemilihan field juga dilakukan untuk optimasi prose eksekusi.

Untuk pengembangan kedepannya dapat dilakukan penerapan algoritma untuk sorting dan pencarian yang lain sehingga didapatkan proses eksekusi sistem yang lebih optimal.

\section{DAFTAR PUSTAKA}

Arief, M. R. 2011. Pemrograman Web Dinamis Menggunakan PHP dan MySQL. Penerbit ANDI Yogyakarta. Yogyakarta.

Cormen. T. H., Leiserson. C. E., Rivest. R. $\mathrm{L}$, and Stein. C. Introduction to Algorithms, Second Edition. MIT Press and McGraw-Hill, 2001. ISBN 0-262-03293-7. Chapter 7: Quicksort, pp. 145-164.

Harsh, B., Khanna, E dan Sudha. 2014. Black Box Testing based on Requirement Analysis and Design Specifications. International Journal of Computer Applications (0975 - 
8887). Volume 87-No.18, (February).

Pranatawijaya, V. H dan Yogiswari, A. M. 2016. Sistem Informasi Praktikum Pada Jurusan Teknik Informatika Universitas Palangka Raya Berbasis Web.

Pranatawijaya, V. H., Putra, P. B. A. A dan Gunawan, V. A. 2016. Pengembangan Perangkat Lunak Generate File Untuk Migrasi Data EPSBED Ke Format Table Feeder PDDIKTI. Jurnal Saintekom,Vol 6, No. 2, September 2016

Pranatawijaya, V. H. 2015. Analisis dan Desain Location Based Service Pada Jurusan Teknik Informatika Fakultas Teknik Universitas Palangka Raya.

Putra, P. B. A. A., Sari, N. N. K dan Pranatawijaya, V. H. 2017. Analisis Dan Desain Website Monitoring Konsultasi Bimbingan Kartu Rencana Studi (KRS).
Putra, P. B. A. A., Pranatawijaya, V. H., Widiatry., Lisa. 2017. Rancang Bangun Sistem Informasi Pencarian Data Mahasiswa Dan Dosen Pada Fakultas Hukum Universitas Palangka Raya.

Rosa A. S dan M. Shalahuddin. 2011. Modul Pembelajaran Rekayasa Perangkat Lunak (Terstruktur dan Berorientasi Objek). Modula. Bandung.

Widiatry. 2016. Rancang Bangun Website Sistem Informasi Praktikum Pada Jurusan Teknik Informatika Univeritas Palangka Raya. Jurnal Saintekom, Vol. 6, No. 2, September 2016.

Zehra, K. 2004. Database Management Systems: A Case Study of Faculty of Open Education. The Turkish Online Journal of Educational Technology TOJET (January) 